Iran: Journal of the British Institute of Persian Studies

This is an Accepted Manuscript version of the following article, accepted for publication in IRAN: the Journal of the British Institute of Persian Studies, 58. pp. 27-40. https://doi.org/10.1080/05786967.2019.1566761

It is deposited under the terms of the Creative Commons Attribution-NonCommercial License (http://creativecommons.org/licenses/by-nc/4.0/), which permits non-commercial re-use, distribution, and reproduction in any medium, provided the original work is properly cited.

Accepted version downloaded from SOAS Research Online: http://eprints.soas.ac.uk/35245

$$
\begin{aligned}
& \text { Iran: Journal of the } \\
& \text { British Institute of } \\
& \text { Persian Studies }
\end{aligned}
$$

Routledge

Taylor \& Francis Group

\title{
THE SASANIAN FIRE TEMPLE OF GACH DAWAR IN WESTERN IRAN: NEW EVIDENCE
}

\begin{tabular}{|r|l|}
\hline Journal: & Iran: Journal of the British Institute of Persian Studies \\
\hline Manuscript ID & RIRN-2018-0014.R2 \\
\hline Keywords: & Gach Dawar, Chahar Taq, fire temple, Sasanian, chronology \\
\hline Abstract: & $\begin{array}{l}\text { In } 1978 \text { a Canadian archaeological mission conducted one season of } \\
\text { excavation at the fire temple of Gach Dawar with the main focus of the } \\
\text { operation on four ancillary rooms added to the exterior of the main } \\
\text { Chahar Taq. The program was terminated in 1979 by the onset of the } \\
\text { Iranian revolution. The new excavation in 2007 re-examined the rooms } \\
\text { originally exposed by the Canadian mission, as well as working in the } \\
\text { heart of the Chahar Taq and other adjacent rooms. The discovery of a } \\
\text { number of cult installations within the Chahar Taq explicitly indicates } \\
\text { that the building was designed as a fire temple. The structural layout and } \\
\text { the pottery recovered from the building imply an original construction } \\
\text { dating to Sasanian times, four building phases identified. The presence } \\
\text { of the Islamic material excavated can be explained as reuse of the } \\
\text { building in subsequent periods. }\end{array}$ \\
\hline
\end{tabular}

\section{SCHOLARONE" Manuscripts}




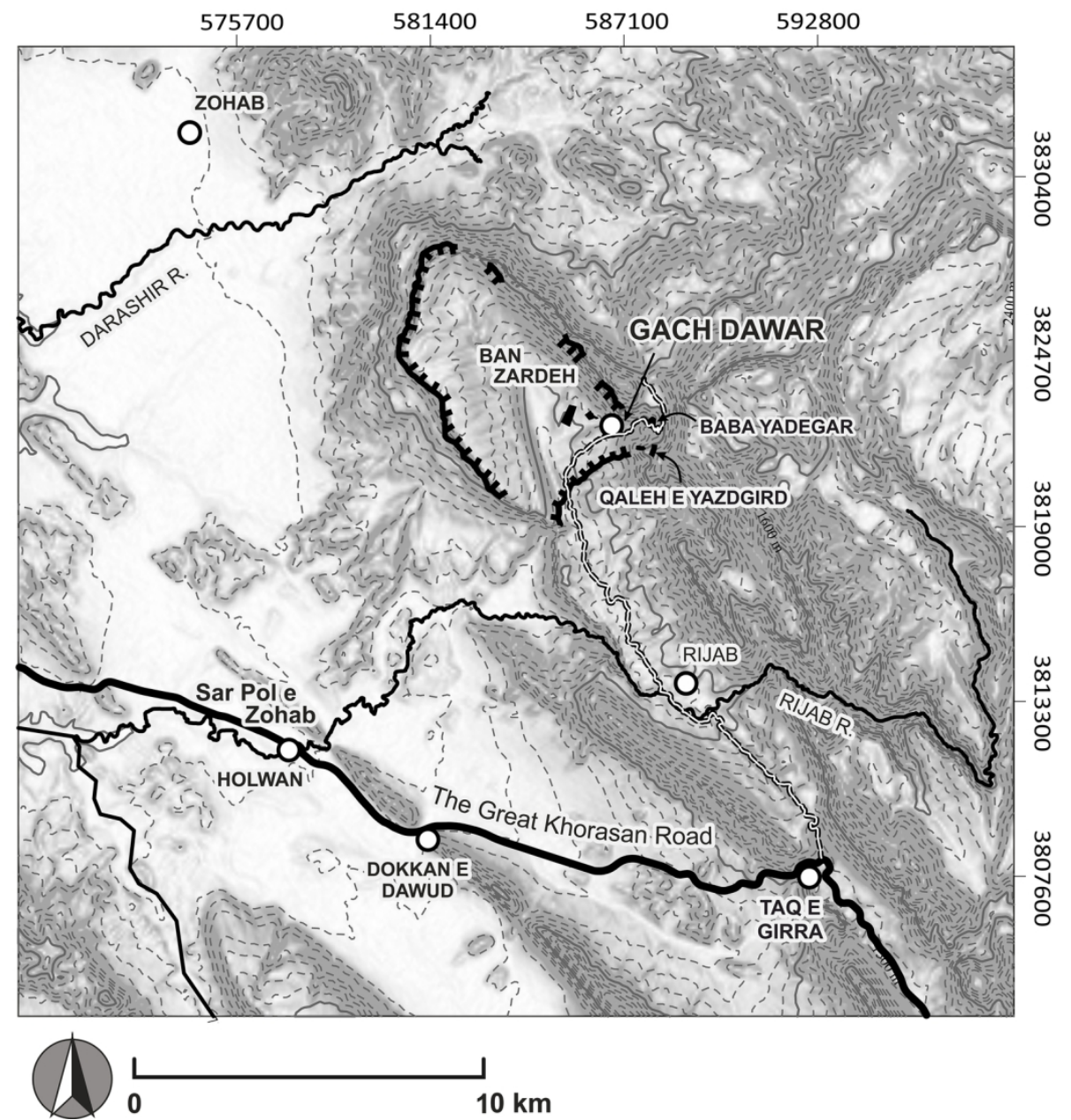

Fig. 1. The location of the fire temple of Gach Dawar (Drawing by R. Yashmi). $148 \times 148 \mathrm{~mm}(300 \times 300 \mathrm{DPI})$ 


\section{KALA DAWAR}

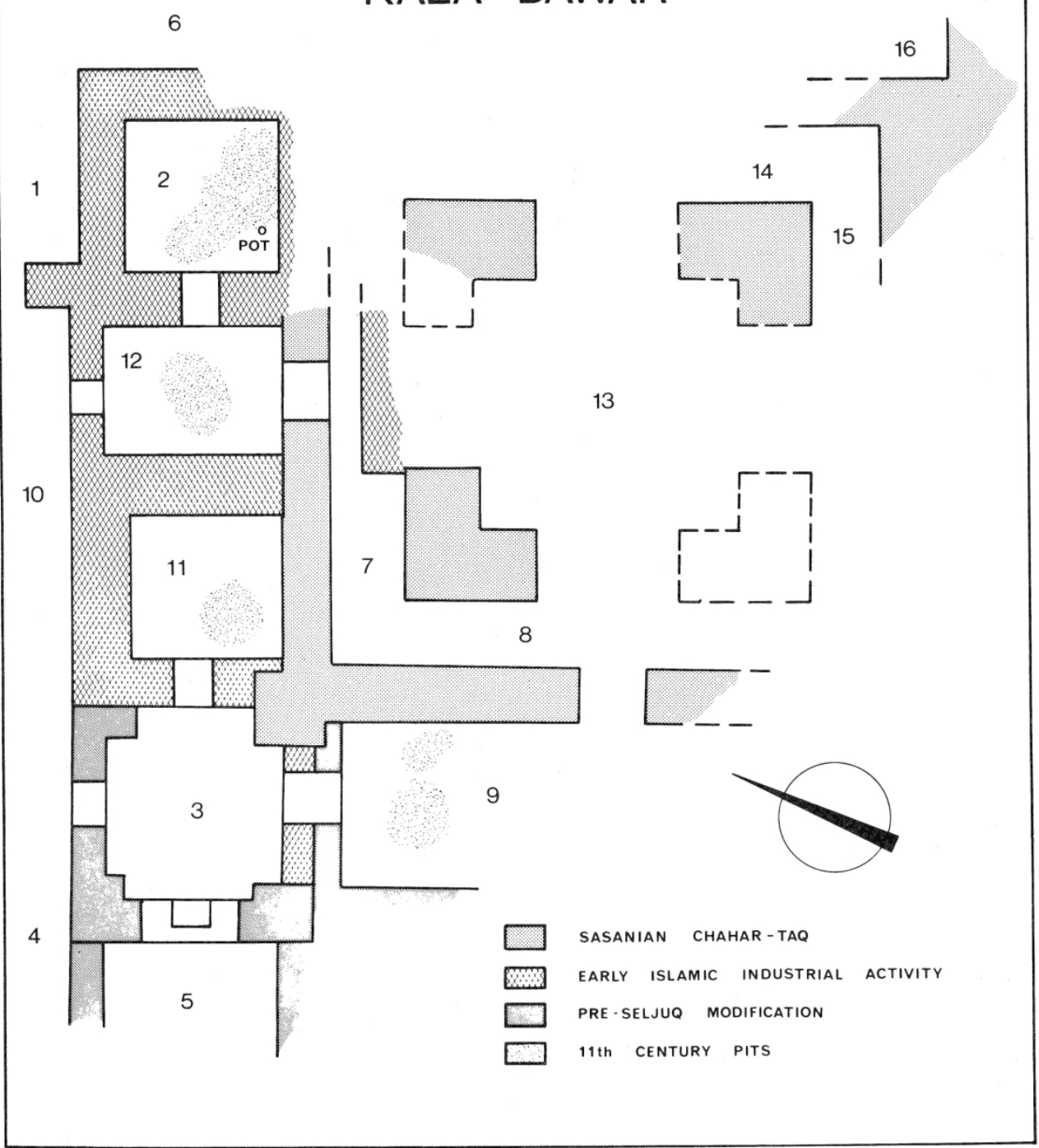

Fig. 2. Plan of the fire temple of Gach Dawar, as excavated, 1978 (Keall 1967: fig. 8). $173 \times 208 \mathrm{~mm}(300 \times 300$ DPI $)$ 


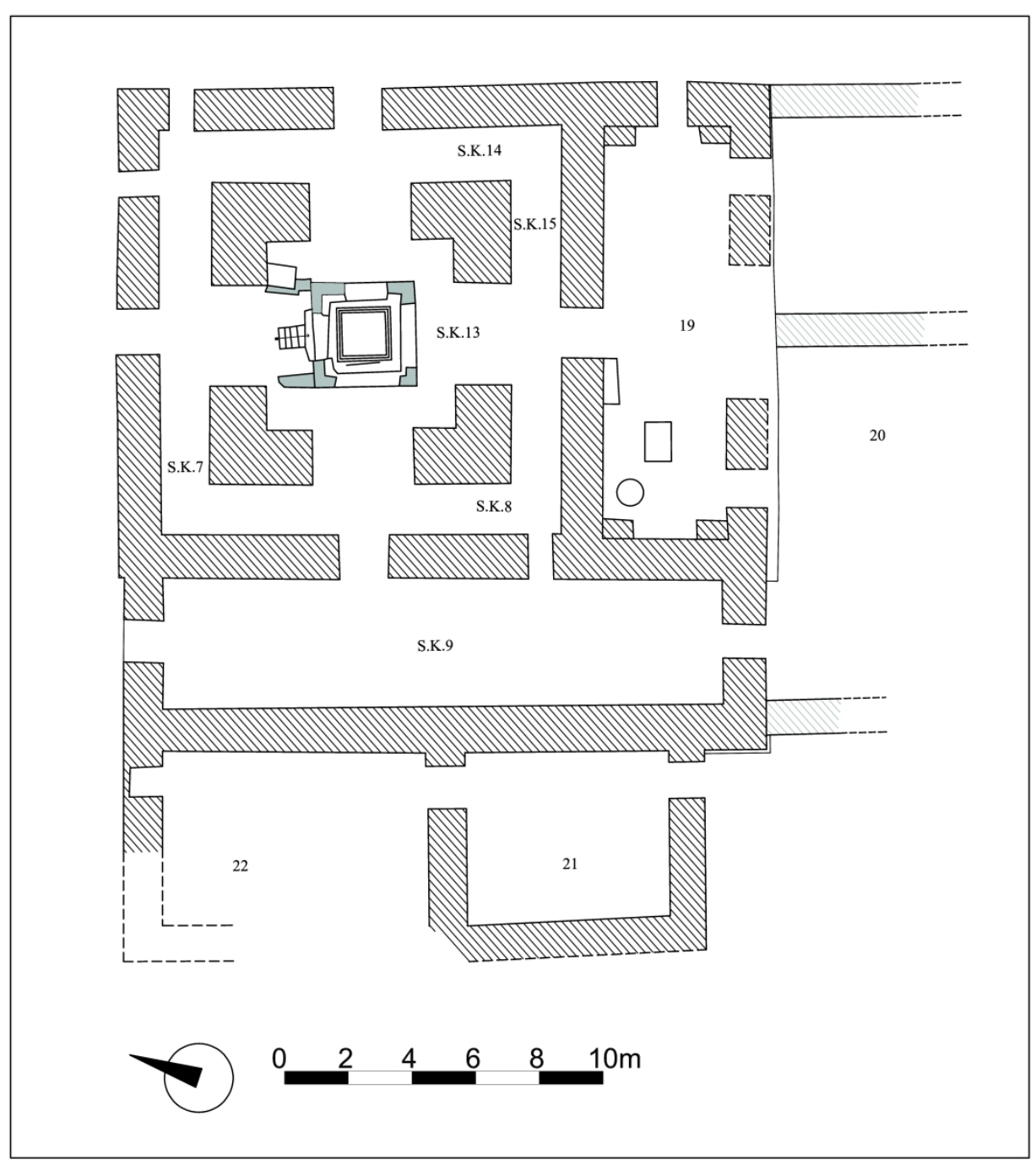

Fig. 3. Plan of the fire temple of Gach Dawar (Phase I), as excavated, 2007. $502 \times 559 \mathrm{~mm}(300 \times 300 \mathrm{DPI})$ 


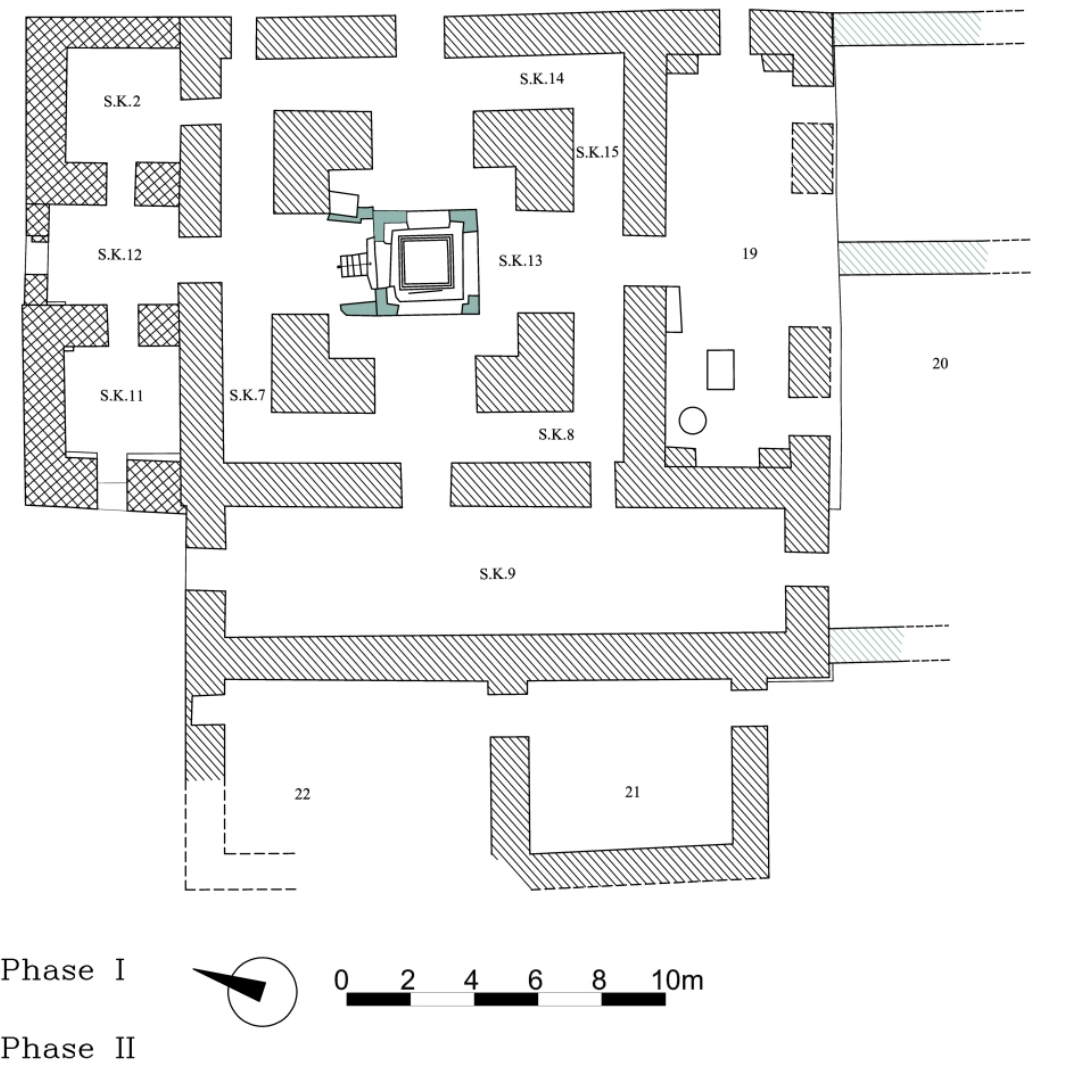

Fig. 4. Plan of the fire temple of Gach Dawar (Phase II), as excavated, 2007. $594 \times 556 \mathrm{~mm}(250 \times 250 \mathrm{DPI})$ 


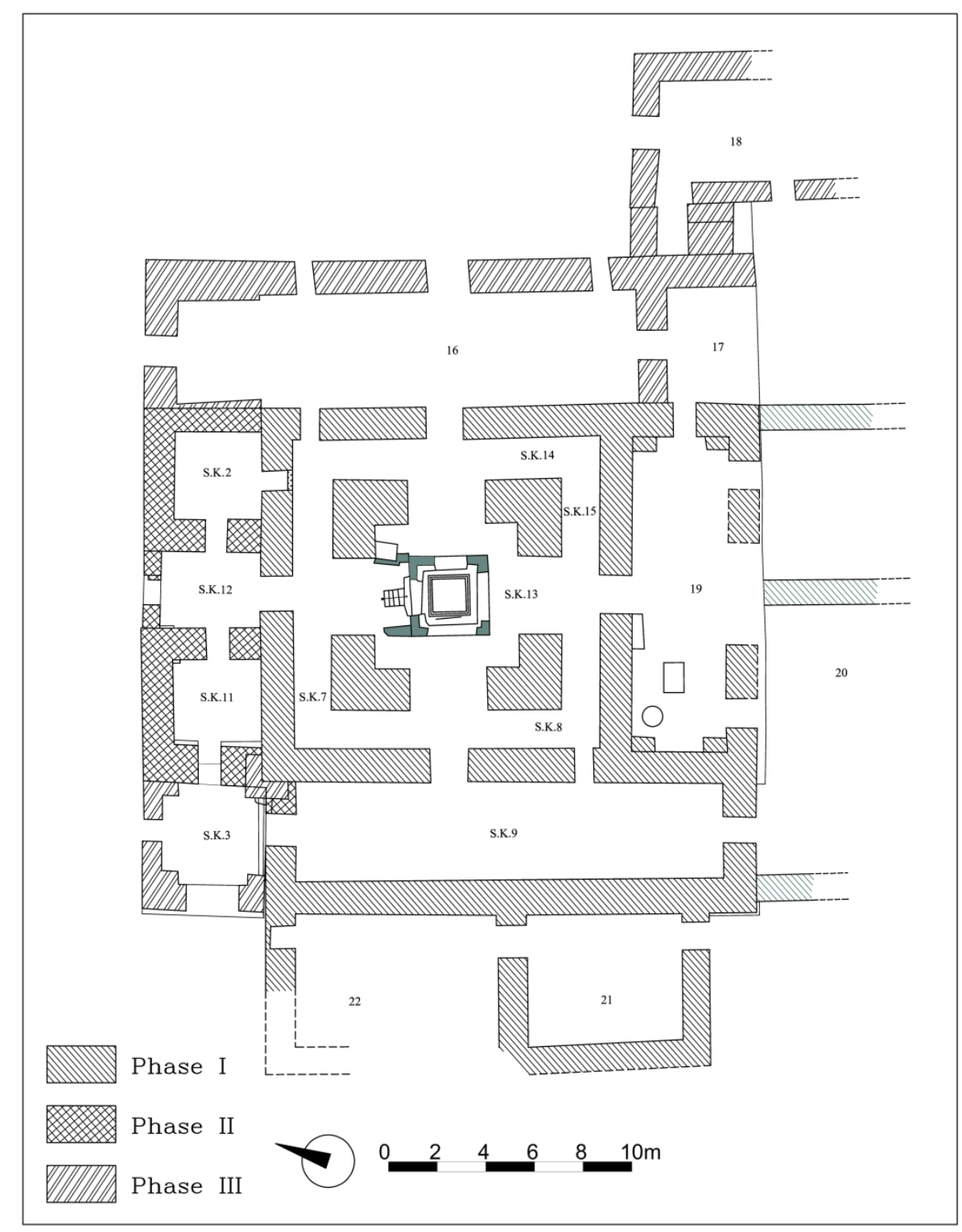

Fig. 5. Plan of the fire temple of Gach Dawar (Phase III), as excavated, 2007. $299 \times 379 m m(300 \times 300$ DPI) 


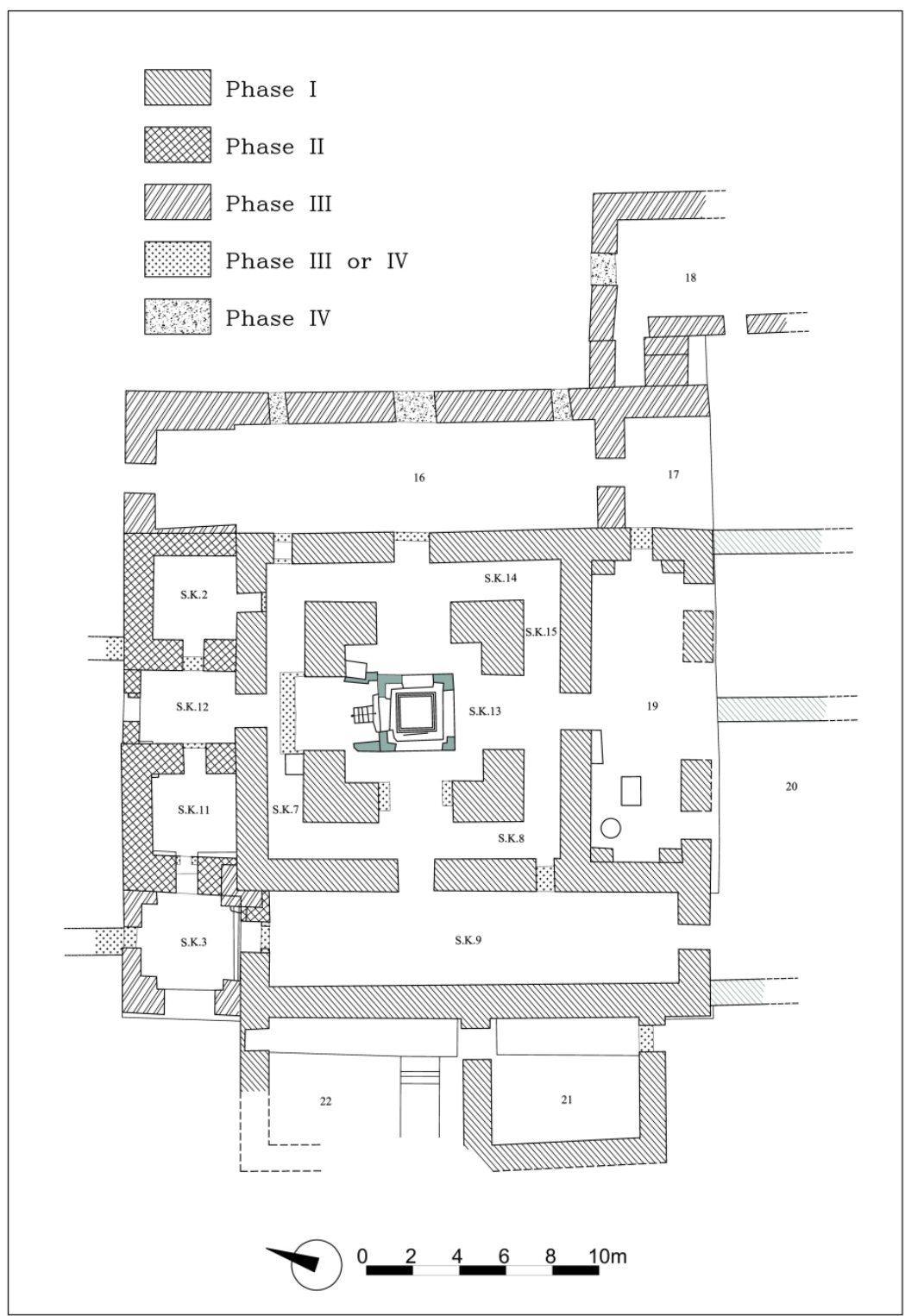

Fig. 6. Plan of the fire temple of Gach Dawar (Phase IV), as excavated, 2007. $297 \times 420 \mathrm{~mm}(300 \times 300$ DPI $)$ 


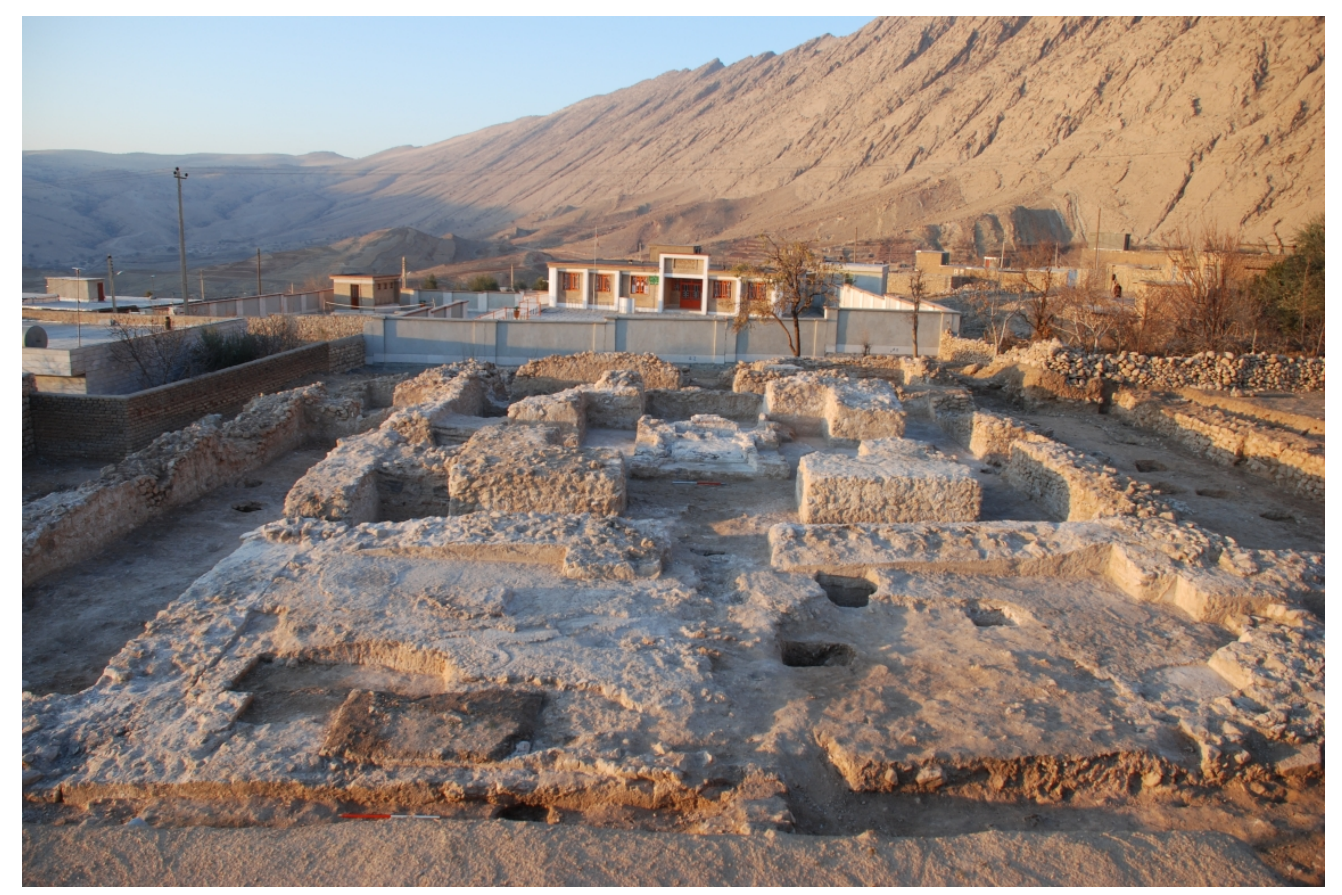

Fig. 7. General view of the fire temple of Gach Dawar.

$327 \times 219 \mathrm{~mm}(300 \times 300 \mathrm{DPI})$ 


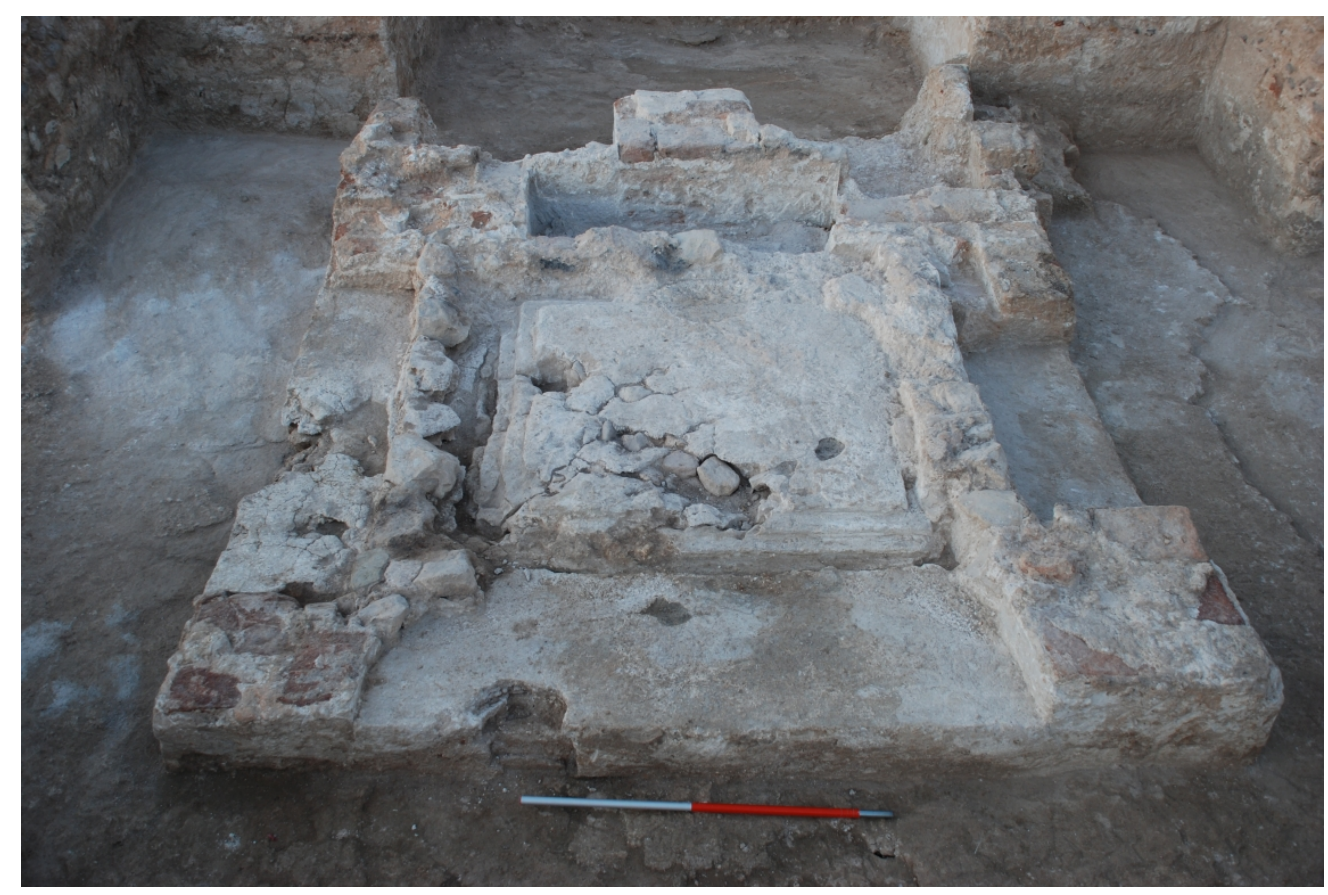

Fig. 8. The fire altar within the Chahar Taq. $327 \times 219 \mathrm{~mm}(300 \times 300 \mathrm{DPI})$ 


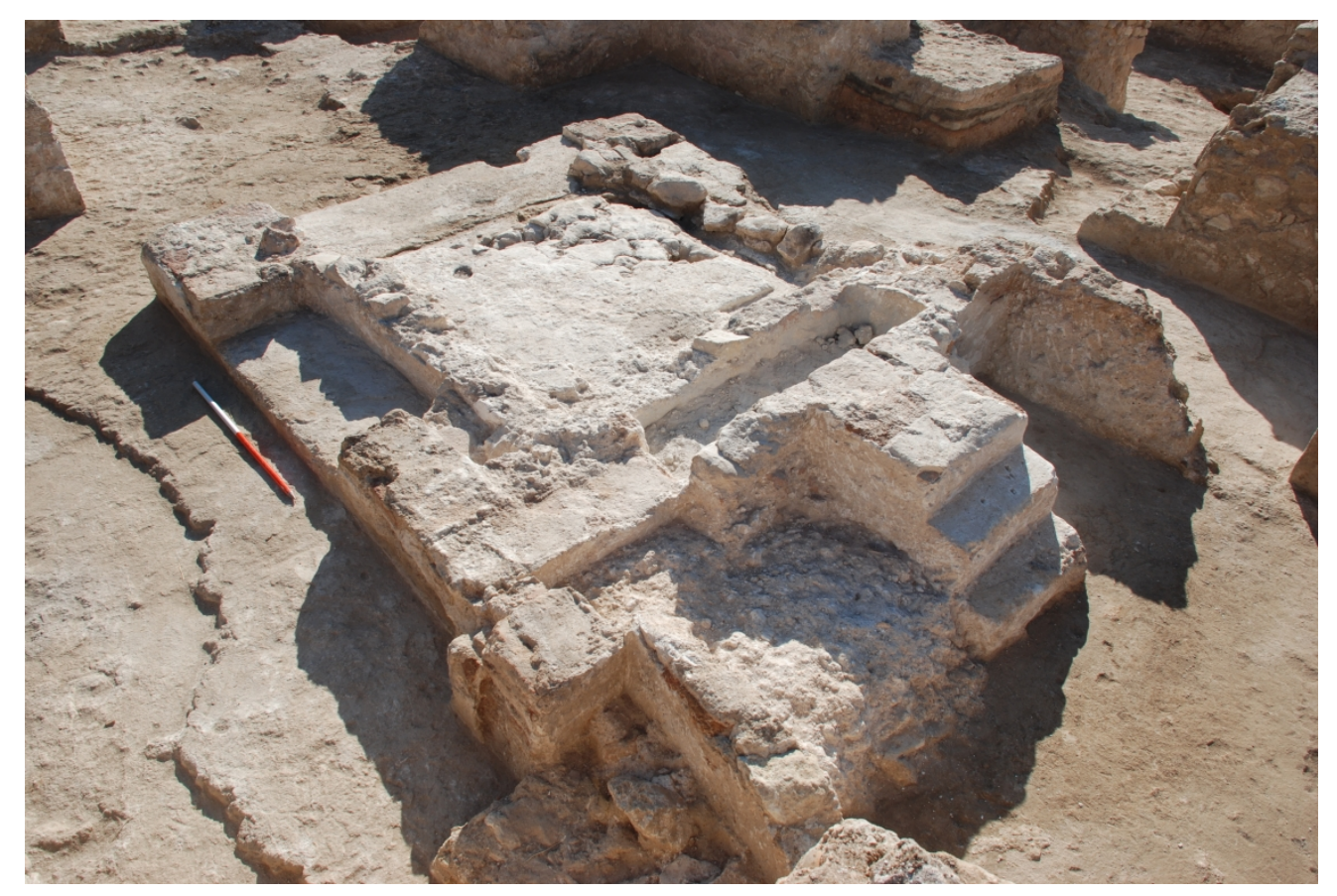

Fig. 9. The fire altar within the Chahar Taq.

$327 \times 219 \mathrm{~mm}(300 \times 300 \mathrm{DPI})$ 


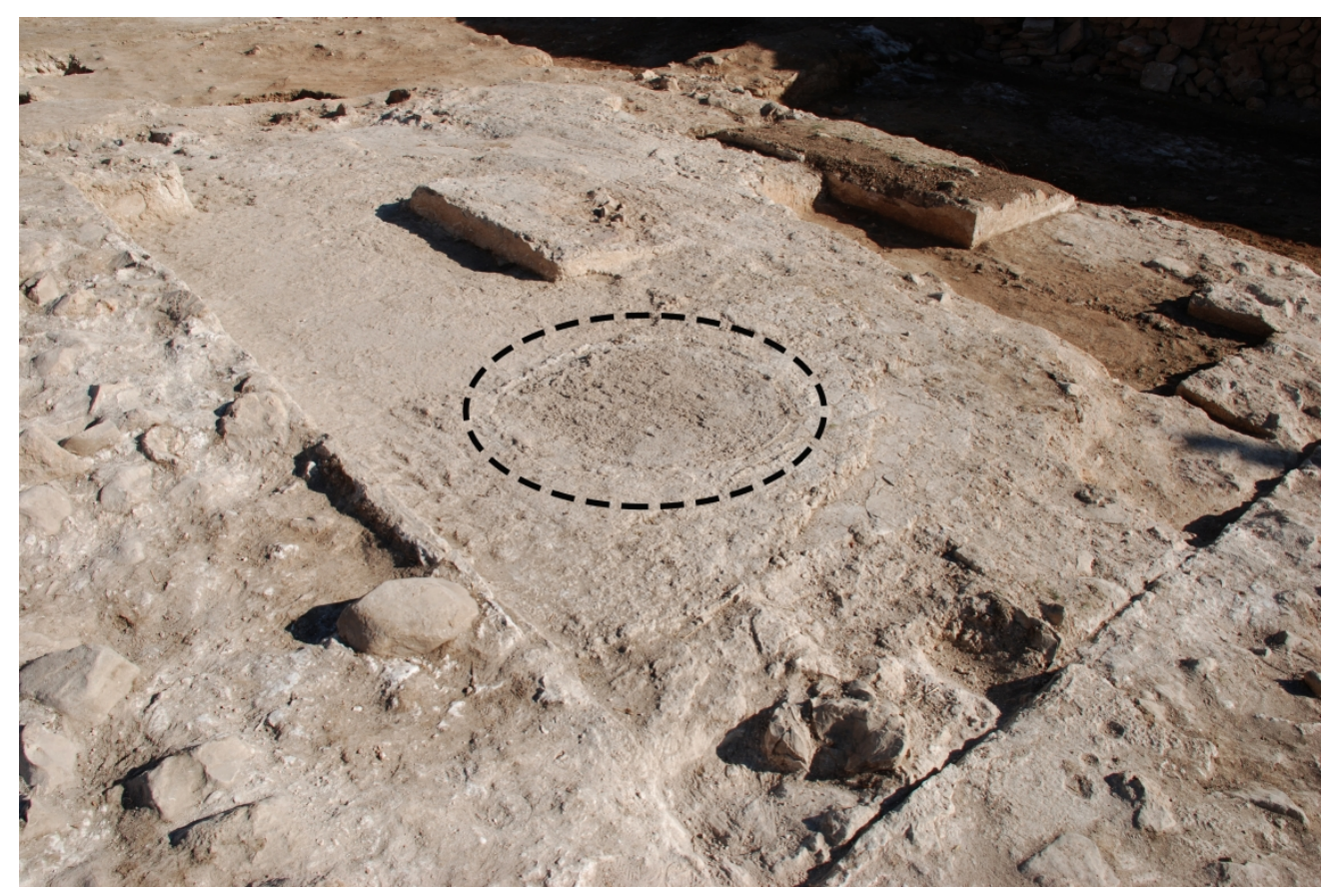

Fig. 10. Details of structures within the entranceway (Tarma).

$327 \times 219 \mathrm{~mm}(300 \times 300$ DPI $)$ 


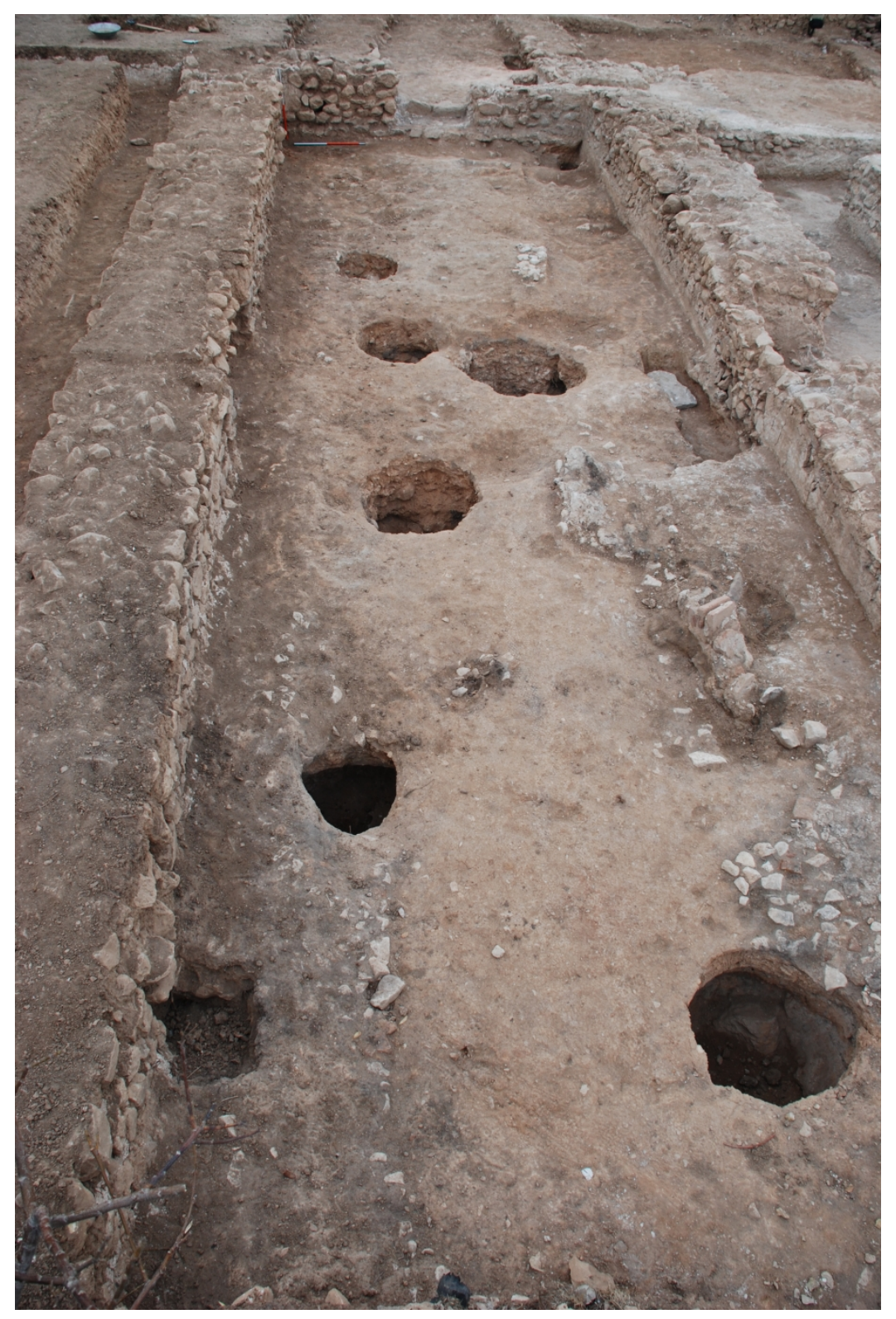

Fig. 11. Seljuq pits dug into room 16. $219 \times 327 \mathrm{~mm}(300 \times 300 \mathrm{DPI})$ 


\title{
THE SASANIAN FIRE TEMPLE OF GACH DAWAR IN WESTERN IRAN: NEW EVIDENCE
}

\author{
By Yousef Moradi and Edward J. Keall \\ The Iranian Center for Archaeological Research and the Royal Ontario Museum \\ Corresponding author: moradiyousef548@yahoo.com \\ Co-authorEdward Keall: edk@rom.on.ca
}


Abstract

In 1978 a Canadian archaeological mission conducted one season of excavation at the fire temple of Gach Dawar with the main focus of the operation on four ancillary rooms added to the exterior of the main Chahar Taq. The program was terminated in 1979 by the onset of the Iranian revolution. The new excavation in 2007 re-examined the rooms originally exposed by the Canadian mission, as well as working in the heart of the Chahar Taq and other adjacent rooms. The discovery of a number of cult installations within the Chahar Taq explicitly indicates that the building was designed as a fire temple. The structural layout and the pottery recovered from the building imply an original construction dating to Sasanian times, four building phases identified. The presence of the Islamic material excavated can be explained as reuse of the building in subsequent periods.

Keywords

Gach Dawar, Chahar Taq, fire temple, fire, Sasanian, chronology, function

\section{INTRODUCTION}

The fire temple of Gach Dawar ${ }^{1}$ is located some $15 \mathrm{~km}$ away from the High Way connecting the Iranian plateau to Mesopotamia, in the district of Dalaho in the province of Kermanshah, western Iran (Fig. 1). The initial discovery of the building remains of Gach Dawar was entirely accidental and unexpected. In the mid-1970s a Canadian archaeological mission was conducting an investigation of the extensive remains that were being interpreted as the stronghold of a Parthian warlord. ${ }^{2}$ An expedition compound was built in order to house the expedition members and provide storage and work space to study the material recovered over the course of the excavations. The dig house was

\footnotetext{
${ }^{1}$ When fire temple was first exposed in 1978 and the excavations described (Keall), the building complex was assigned a site name in honour of the local land-owner (Dawar Karamkhani) who had generously offered the stones in his field for construction of the Canadian Mission compound wall. The original published name was "Kala Dawar", using the Kurdish version of Qal'eh (Castle) to distinguish it from the Upper Castle of Qaleh-i Yazdigird. But since there is a tendency for Iranians to use the Persian version of the man's name (= Davar), it has resulted in an awkward hybrid Persian-Kurdish term. Many visible parts of the ruined stronghold do have legendary names associated with them (e.g. Shah Neshin), but indiscriminate piles of stones and stubs of walling are generically called "Gach" (gypsum) - hence the new site label of "Gach Dawar".

${ }^{2}$ Keall 2008: 824; Idem 1994: 258; Idem 1983: 44.
} 
built using the local tradition, which involved walls constructed with roughly hewn filed stone. In many parts of the area collapsed walls were an impediment to ploughing. Farmers were in the habit of piling loose stone in a heap in one part of the field. One of these local farmers, Dawar Karamkhani, generously offered exploitation of one such pile of field stone for the purpose of the Canadian mission's building program. When the top stones were removed, the traces of three masonry piers were revealed. Their positioning and L-shape immediately led to the suggestion that they were parts of a Chahar Taq. The decision was made to conduct a controlled excavation. The main focus of the operation was concentrated in four rooms (Rooms S.K.2, S.K.3, S.K.11, S.K.12) added to the exterior of the main Chahar Taq (Fig. 2). At the time of the publications of this work, the presence of Islamic period pottery and a great deal of ash in these rooms led to the conclusion that they were workshops dated to the early Islamic period and added on the outside of a derelict Chahar Taq. ${ }^{3}$ The program was terminated in 1979 by the onset of the Iranian revolution.

With the break out of Iran-Iraq war in 1980 the fields around the Chahar Taq were bulldozed for use by the Iranian military. Some bulldozed debris was piled on top of the previously exposed archaeological remains. With termination of the hostilities, when the military left the region, the flat area around the Chahar Taq became attractive place for the villagers of old Zardeh to build new homes. Gradually these structures started to encroach upon the archaeological site of Gach Dawar. This thread led to the decision by the authorities of the Iranian Cultural Heritage Organization and Tourism (ICHOT) to conduct a rescue operation. The new excavation in 2007 re-examined the rooms S.K.2, S.K.3, S.K.11, S.K.12 originally exposed by the Canadian mission, as well as working in the heart of the Chahar Taq (S.K. 13) and its surrounding corridor (S.K. 7, 8, 14, 15), and other adjacent rooms including rooms 9 and 16-22 (Figs. 3-7). The discovery of a number of cult installations within the Chahar Taq explicitly indicates that the building was designed as a fire temple. The structural layout and the pottery recovered from the building imply an original construction dating to Sasanian times, four building phases identified. The presence of the Islamic material excavated can be explained as reuse of the building in subsequent periods.

\footnotetext{
${ }^{3}$ Keall 1979: 158; Keall and Keall 1981: 33-34.
} 


\section{BUILDING REMAINS}

\section{Wall construction}

The walls and piers of the exposed building were constructed out of rubble stone masonry comprised mostly of undressed field stone embedded in generous quantities of gypsum mortar. A relatively flat side was chosen for each stone at the face of the wall. The core of the wall was an irregular pack of smaller stones. No horizontal layering in the masonry was discerned, but some vertical joints were documented in room 18. In the ancillary rooms on the north side of the Chahar Taq some baked bricks were used, presumably recycled for expediency. The finished wall surface was comprised of a thin layer of smooth gypsum plaster laid over a thick, rough base coat (approximately $10 \mathrm{~cm}$ thick). Numerous layers of thin finishing coats were documented, indicating successive repairs.

\section{Floors}

The base layers of the floors were comprised of thick bands of dirt-for leveling purposes - covered by a thin layer of gypsum mortar, onto which cobble stones were randomly set. The stones were then buried by a thick screed of gypsum mortar poured in separate batches. The joins between each batch were covered by the finishing coat of plaster. As with the walls, numerous finishing coats indicate re-plastering repairs.

\section{Roofs}

On the analogy with other better preserved fire temples one may assume that the Chahar Taq chamber was once roofed with a dome, and the circumambulatory corridor with barrel vaults. The presence of a fragment of fallen brick roof vaulting in room 16 suggests the possibility that the ancillary rooms were also brick vaulted. However, the discovery of a stone roof roller in the debris outside of building ${ }^{4}$ may indicate that the top surface of the roofs were flat, made of mud poured over the brick vaults. The same principle can apply in the case of entrance hall 19 , fronted by two masonry piers that flank a wide entrance way, though a flat wooden roof cannot be discounted. Since that would imply a different roofing system, it might be reasonable to postulate that a barrel

\footnotetext{
${ }^{4}$ Keall and Keall 1981: 34; Keall 1982: 59.
} 
vault was carried over arches on the open side of the hall. Unfortunately, there is no tangible evidence to indicate how the cruciform room 3 was roofed. One certainly cannot rule out entirely the idea of a domed roof.

\section{Layout and building phases}

As already mentioned above, the building complex of Gach Dawar was constructed in different stages. This is evidenced in places where walls are bonded or not. But, while the sequence of the building activity can be determined, it is exceedingly difficult to judge the amount of time that separates these construction activities, whether it was years, decades, or centuries.

\section{Phase IA-B}

The original part of the complex (Phase I) consists of four L-shaped piers representing a classic Chahar Taq, together with a circumambulatory corridor. The inner floor space of the Chahar Taq measures $5.95 \mathrm{~m}$ by $5.95 \mathrm{~m}$ (Fig. 3). The corridor is $1.60 \mathrm{~m}$ wide. At the time of the conclusion of the excavations in 2007 it was still only possible, through a hole in the floor, to see a built feature on a lower floor that purports to be an earlier version (Phase IA) of the cult installations that have been documented on the upper floor from Phase IB. The explanation for the higher floor level stems from the fact that the surface water run-off from the nearby cliffs resulted in the accumulation of sediments against walls of the building. This made it impossible to get through the doors. To deal with this problem, gravelly fill was intentionally dumped inside the building, to make the floors level with the ground outside. This made it necessary to provide new cult installations on this higher Phase IB floor. The new installations in Phase IB consist of a raised platform, measuring $2.55 \mathrm{~m}$ by $2.55 \mathrm{~m}$, made of rubble masonry and accentuated at the four corners by small L-shaped piers made of baked brick. There is a basin-like depression in the center of the platform in which stands a four stepped masonry feature likely designed to serve as a podium, as the base for a fire altar (Figs. 8-9). However, the excavation has not revealed an actual fire altar. Stepped podiums of this type have been documented in the sanctuary of PD in Takht-e Solayman ${ }^{5}$, the fire temple of Turang Tappeh ${ }^{6}$, and the fire

\footnotetext{
${ }^{5}$ Huff 2008: fig. 3.

6 Boucharlat and Lecomte 1987: 65-69.
} 
temple of Mohammad Abad near Borazjan. ${ }^{7}$ Parallel to these podiums was also found at the site of Imamzadeh Mohammad Vali Beig in Khorasan, now held at the Mashhad Museum ${ }^{8}$.

Conceivably the small L-shaped piers may be the remnants of pillars designed to support a canopy structure and protect the sacred fire from contamination as amply attested in both ancient and modern Zoroastrian practice. The presence of a canopy structure has been reported in the fire temple of Turang Tappeh, where a depression at each corner of the platform would have held a canopy structure, under which the fire altar stood. ${ }^{9}$ Another example of this type of structure can be found in the cruciform room B at Takht-e Solayman. This room contains a square, basin-like enclosure made of baked brick, with four depressions in its corners. It has been suggested that these depressions were used to fix the comer posts of a light canopy. ${ }^{10}$ Further example can be provided by a canopy structure in the fire temple of Mil-e Milagah. ${ }^{11}$ A canopy structure under which sacred fires burn can also be found in the main sanctuary of modern Zoroastrian fire temples, for example the fire temple of Dar-e mihr-e Dulatkhane at Kerman, which was constructed in 1901. ${ }^{12}$ The four stepped podium was remodelled at some time by the addition of masonry at its sides that obscured the steps and was likely designed to raise the height of the feature. In the back part of the platform is a rectangular trough $(1.62 \mathrm{~m}$ by $25 \mathrm{~cm}$ ) designed to contain ashes from the fire, pending further sacred use. The trough was full of ash when excavated. It is still customary in Zoroastrian societies for ashes from the sacred fire to be distributed amongst members of the community. ${ }^{13}$ The survival of the ash in the trough, preserved under fallen masonry, implies that the building still functioned as a fire temple until the Chahar Taq collapsed. Behind the platform is a plastered brick masonry feature consisting of four steps (the length of each step is $65 \mathrm{~cm}$, the depth is $20 \mathrm{~cm}$, and the height is $22 \mathrm{~cm}$ ) that presumably provided access for a priest to attend to the sacred fire. The steps were built as part of the original platform structure (Fig. 9).

7 Yaghmaee 2015: 51-52, figs. 2, 3.

8 Rahbar 2015: 92-98.

${ }^{9}$ Boucharlat and Lecomte 1987: 65-69.

${ }^{10}$ Naumann 1960: 3053-3054; Huff 2008: 3.

${ }^{11}$ Moradi 2016: 48.

${ }^{12}$ Boyce 1966: 54-56, 58.

${ }^{13}$ Drower 1944: 77; Huff 2002. 
Phase I also involved the construction of a number of rooms (S.K.9, 21, 22) on the southwestern side of the Chahar Taq, and a rectangular entrance hall (19) on its southeastern side, measuring $3.95 \mathrm{~m}$ by $11.85 \mathrm{~m}$ (Fig. 3). It is hypothesized that on the open side of the entrance hall there were two rectangular piers-one of them reconstructed here-which can be best explained as the supports for arches that carried the roof, as described above. Although most of the Sasanian fire temples do not have features of this kind, the southern fire temple of Sarab-e Murt has a similar entranceway plan (an open room, locally defined as a Tarma). Traces of masonry outside of the entrance can be seen as the compound walls surrounding an open courtyard, together with a provision for stepping up the courtyard surface to accommodate the sloping ground. The interior of the entrance hall contains a number of features including traces of a circular installation in plaster $(80 \mathrm{~cm}$ in diameter), with traces of burning, and a rectangular masonry platform measuring $83 \times 123 \times 20 \mathrm{~cm}$ (Fig. 10). No explanation can be offered here for the purpose they served. Flanking the western jamb of the doorway that connects the entrance hall with the Chahar Taq there is a single projection $(42 \times 143 \times 70$ $\mathrm{cm}$ ), possibly a bench serving the same unspecified function as two benches located inside the Chahar Taq. In the four corners of the entrance hall there are piers that create recesses on the short sides of the hall. At the eastern end, the recess furnishes access to the entranceway 17.

Room 9 is a long rectangular hall measuring $4.10 \mathrm{~m}$ by $17.60 \mathrm{~m}$, and set at a much lower level than the rest of the complex, because of the underlying terrain. This difference in height was accommodated by the provision of steps through a main doorway into the Chahar Taq. The smaller doorway along the eastern wall of the room was later blocked up, as was also the doorway that once led into the cruciform room (room S.K.3). No explanation can be given for why there is a reused cylindrical engaged column of gypsum mortar set on the threshold of the doorway from the courtyard into the room.

On the southwestern side of the complex there is a unit consisting of two rooms (21, 22) connecting with each other, built as an integral part of the complex, without any direct connection to the core of the fire temple. The structures are severely damaged so that the archaeological record is incomplete. The only preserved doorway to the outside 
in the southern wall of room 21 has been blocked up. A wide bench (1.70 $\mathrm{m}$ in width) runs the entire length of the two rooms, including through the doorway between them. Attached to the bench in room 22, at a right angle to it, is a lower three stepped feature (1.67 $\mathrm{m}$ in width and $4.60 \mathrm{~m}$ in length) that may have served as a ramp to reach the platform. At the far northern end of the bench in room 22 there is a small niche $(95 \mathrm{~cm}$ by $120 \mathrm{~cm}$ ) in the wall at the same height as the top of the platform.

\section{Phase II}

For the three ancillary spaces on the north and northwestern side of the complex (Rooms S.K.2, S.K.11, S.K.12), there is evidence of a first stage of construction that remains enigmatic pending further examination. The remains that are discernible may represent either a remodelling or building upon unfinished walls. These spaces originally represented a unit consisting of two rooms (S.K.2, S.K.11) flanking an ayvan (S.K.12) that provided an entrance into the Chahar Taq. Subsequently the ayvan was modified by building a doorway on the open side, and by the blocking of the doorways into the side rooms. Access to the eastern side room (S.K.2) was now provided only by the doorway opening from the circumambulatory corridor (Fig. 4).

The floors of all these spaces were originally furnished with a thick layer of plaster screed that is flush with the floor inside of the Chahar Taq. In room S.K.2 a relief decorated blue green glazed jar fully enveloped with gypsum plaster that had been deliberately embedded in a sealed context within the floor screed. ${ }^{14}$ Given that the pot was found later and broken into, during the digging of a pit through the floor, we may surmise that it once contained something precious. Since the adjacent rooms were also pitted, but not the interior of the main sanctuary, one may speculate about the possibility of a living memory that treasure was buried in this port of the complex. Of course, one cannot dismiss the possibility that the discovery was entirely accidental. ${ }^{15}$

\section{Phase III}

The third major phase of building activity (Fig. 5) involved the construction of a long rectangular room (16) on the northeastern side of the Chahar Taq, and a small rectangular entranceway (17). Attached to the western side of room S.K.11 is a space of quite

\footnotetext{
${ }^{14}$ Keall 1979: 158-159; Keall and Keall 1981: 33-34, fig. 6, pl. Vb; Keall 1982: 59.

${ }^{15}$ The deliberate digging a pit inside a fire temple in antiquity, in order to find treasure, has been documented at Takht-e Solayman (see Huff 2008: 3)
} 
different character (S.K.3). Square in its interior layout ( $4.20 \mathrm{~m}$ by $4.25 \mathrm{~m}$ ), it has shallow recesses on all four sides, giving the sense of a cruciform plan. The room was initially accessed by two doorways from the outside, and two others into rooms 9 and S.K.11. The southern doorway was subsequently turned into a niche and the northern exterior doorway was blocked in Phase IV. As well, later, a bastion was built against the exterior outside of the blocked doorway. Room 16 is a relatively long rectangular hall measuring $18.82 \mathrm{~m}$ in length and $4.65 \mathrm{~m}$ in width, entered by way of several entrances from the exterior, as well as from the interior of the Chahar Taq. The doorways in the eastern exterior wall were eventually blocked up in Phase IV to cope with the rising accumulation of run-off sediments washed from the neighboring hillside. Adjoining the eastern side of entranceway 17 are the remains of a rectangular room (18), including a narrow and deep recess in its north western corner.

Entranceway 17 is rectangular in plan measuring $3.68 \mathrm{~m}$ by $4.72 \mathrm{~m}$ overlooking the courtyard. This entranceway provides access into spaces 16-20.

\section{Phase IV}

This phase represents the blocking of some doorways (Fig. 6). It is difficult to determine the chronological sequence in which the doorways were blocked. However, we can safely suggest that the three doorways in the eastern wall of room 16 were blocked in medieval period when the building was functioned as an industrial workshop. This suggestion is confirmed by the presence of ash under the blocking walls.

\section{BUILDING CHRONOLOGY AND USE}

As is the case with most Sasanian fire temples, providing a precise construction date for the Gach Dawar complex is impossible at present. The excavations went down to a considerable depth below the plaster floors wherever allowed. But no archaeological material was found. However, the recovery of a reasonable amount of Sasanian pottery in almost all parts of the complex gives of a clear indication of the time when the structure were being used, but not for the time when it was originally built. A significant problem was encountered in the Gach Dawar excavations. Extensive pit digging and subsequent 
activities in the building resulted in mixing of ceramics from different chronological periods. The stratigraphy is therefore of very little assistance in the construction of a reliable chronology for the pottery recovered from this site. The presence of industrial activities carried out during the $10^{\text {th }}-11^{\text {th }}$ century on the Sasanian floors attests to the fact that the stratigraphy was greatly confused. As a consequence, the sherds excavated from this site were almost never recovered from a stratum that could be definitively dated to the period in which they had been manufactured and used.

The presence of three silver dirhams from the Buyid period found in the Chahar Taq, ${ }^{16}$ together with the existence of ash inside the above-described trough-representing the last rituals conducted inside the building-clearly indicates that the complex was still functioning as a fire temple in the early Islamic centuries. The later use of the complex as an industrial workshop in Seljuq times will be discussed later.

The presence of the cult installation within the Chahar Taq explicitly indicates that this complex functioned as a fire temple. There have been a number of scholarly attempts to classify the type of Sasanian fire temples based on the ground plan and the cult installations found in them. For example, Barbara Kaim purposed a theory that the hierarchy of sacred fire is not reflected in the layout of the building but rather in the cult installations. She argues that those fire temples that possess a basin-like structure in which a fire altar without stepped base stood may have housed the Atash Bahram (provincial fire) ${ }^{17}$ ), while the fire temples with a stepped fire altar accommodated the Atash Adaran (local fire). ${ }^{18}$ The discovery at Gach Dawar of a four stepped podium placed inside a basin-like structure demonstrates that Kaim's theory is not universally valid.

It is also argued here that one has to be cautious about employing the classification of ancient fire temples based on the contemporary Zoroastrian fire temples in both Iran and

\footnotetext{
${ }^{16}$ The ruler mentioned on coins nos. 1 and 2 is Samsam-al-Dawla, son of Azod-al-Dawla: caliph (on reverse) is al-Ta'i'. Unit of date is not legible, so 373-375 A.H is the closest we can get to a date. Coin no. 3 belongs to 'Azod-al-Dawla Abu Shoja. These three coins were struck at the mint of Madinat-al-Salam (Baghdad).

We are grateful to Luke Treadwell and Abdullah Ghouchani for providing readings of the inscriptions on the coins.

${ }^{17}$ For the classification of Zoroastrian fires into three hierarchical categories, namely the Atash Bahram (provincial fire), Atash Adaran (local fire) and Atash Dadgah (family fire) see Modi 1937:168-184; Boyce 1968: 52; Idem 1975: 463; Idem 1979: 110; Idem 1987: 1-5; Choksy 2006: 329; Idem 2007: 252.

${ }^{18}$ Kaim 2004: 334-336.
} 
India as proposed by Gerd Gropp. ${ }^{19}$ Although there are some superficial similarities between the modern fire temples and the ancient ones, there is no gradual continuation to document between the ancient fire temples and the modern ones that one can confidently use to claim that the modern fire temples are counterparts to the ancient ones. ${ }^{20}$

The unequivocal evidence that the Gach Dawar complex functioned as a fire temple underlies the importance of revisiting the scholastic debate about the role of Sasanian Chahar Taqs. It is also highly significant that the Gach Dawar complex is comprised of a number of associated, but separated units where we can assume a variety of religious and community activities were conducted in the building other than purely fire rituals. ${ }^{21}$

As for the Chahar Taq we have demonstrated its role as a space for the presentation of the sacred fire. It is tempting to see the small cruciform (room 3) as the sanctuary (atashgah) to house the perpetual sacred fire, while it was not exposed to the believers in the main Chahar Taq, following the line of argument originally presenting by André Godard $^{22}$ and Kurt Erdmann ${ }^{23}$ and accepted by many subsequent scholars. ${ }^{24}$ However, there is not a shred of archaeological evidence to substantiate this idea in the case of Gach Dawar.

Following the argument that the complex served a variety of community purposes, one can suggest that the two rectangular long rooms $(9,16)$ were spaces serving as gahanbarkhane for seasonal festival celebrations and yazishngah, a place of worship for the liturgical recitation of the Yasna, the Visperad and the Wìdēwdād. There was no archaeological evidence recovered in the two roomed, long bench unit to clarify the kind of activities conducted there. Nevertheless, there are many textual references to ritual presentation of foodstuffs (Stum ritual) to commemorate the souls of the deceased. ${ }^{25}$ Perhaps the presence of the long bench supports this suggestion. For all the other rooms there is no satisfactory confirmation of their specific function.

\footnotetext{
${ }^{19}$ Gropp 1969: 148-150.

${ }^{20}$ Moradi, 2016: 49-50.

${ }^{21}$ For the discussion on the activities carried out within the ancient Zoroastrian fire temples see Huff 2004 : 465; Huff, 2011: 104; Callieri 2014: 80-81, 199.

22 Godard 1938: 7ff.

${ }^{23}$ Erdmann 1941: 35 ff.

${ }^{24}$ Naumann, 1965: 661-662; Vanden Berghe 1968: 38-41; Schipmann 1971: 504; Azarnoush 1989: 653654.

${ }^{25}$ For the Stum ritual and food offering in fire temples see Kotwal and Choksy 2004: 389-401.
} 


\section{SPONSORSHIP OF THE GACH DĀWAR FIRE TEMPLE COMPLEX}

It is a huge challenge to offer any convincing explanation for the sponsorship of the impressively large fire temple complex of Gach Dawar on a remote hillside in the mountains of western Iran in Sasanian times. There are certainly numerous textual attestations for the sponsorship of fire temples in Sasanian times. A revealing example, frequently cited in western scholarship are the four fire temples constructed in honour of his four sons by Sasanian Mehr-Narseh, court minister of Kings Yazdgerd I (399-421 A.D.), Bahram V Gor (421-439 A.D.) and Yazdgerd II (439-457 A.D.). ${ }^{26}$ But for none of these citations are there any descriptions of their physical character and layout. For sure, there are physical examples of fire temples documented in remote settings in different parts of ancient Iran, albeit their intended purpose and role is not at all clear. If sponsorship of Gach Dawar fire temple complex can be envisaged as serving the needs of more people than just those on this remote hillside, it would have been more logical to have constructed it with greater accessibility from the main highway below the cliffs that delineate one edge of the ancient Parthian fortress of Qaleh-i Yazdigird.

It was the comparative lack of natural resources for the building of this extensive fortress that led excavator Edward Keall to conclude that there had to be an outside source of capital to construct such an extensive stronghold - using vast quantities of building materials and necessarily employing huge teams of workers to construct the defensive walls. Keall argued that the likely source of this capital was the possibility of extracting tariffs from wealthy caravans that were obliged to pass through the famous nearby Zagros Gates, the most logical way to move between the plateau of western Iran and Mesopotamia. The artwork of the Parthian palace within the stronghold has been judged to be $2^{\text {nd }}$ - early $3^{\text {rd }}$ century A.D in date. The combination of elaborate stronghold and lavishly decorated palace leads to the conclusion that this was the work of a Parthian warlord who could operate unrestrictedly in the insecure decades of the last century of the Parthian era. ${ }^{27}$

\footnotetext{
${ }^{26}$ Tabari 1999: 105.

${ }^{27}$ Keall 1994: 258; Idem 1983: 44; Idem 2008: 824.
} 
Although we have no specific accounts of the first Sasanian king campaigning in western Iran when he defeated the last remaining Parthian king, Artabanus, it is known that Ardashir I was obliged to conduct a systematic military campaign to stamp out Parthian resistance to the new regime. While the story narrated in the Pahlavi chronicle of Ardashir's karnamag is obviously largely apocryphal, the challenges facing Ardashir in his quest to battle against Madig, the King of the Kurds, in Media ${ }^{28}$ definitely ring true for Qaleh-i Yazdigird. It certainly makes sense that the Sasanian authorities would have judged the lifestyle of the Parthian warlord to be no longer tenable under the new political order. With the warlord and his retainers disempowered it is tempting therefore to argue that the fire temple complex of Gach Dawar represents a physical attestation of the new Iranian state's power, a clear underlining of the fact that the era of the Parthian warlord was over. Conceivably the land and properties seized by the Sasanian authorities in the era of Ardashir were directed towards construction of the fire temple, which can help explain its impressive character and size.

This radical interpretation can be corroborated with the similarity of the Chahar Taq with the stone mortar-masonry construction of Takht-e Neshin at Firuzabad, which is an example of a classic Chahar Taq built by Ardashir I on the account of the Karnamag and other medieval sources. ${ }^{29}$ It is challenging to identify in later centuries the potential source of the revenues that would have been necessary to both construct and maintain a fire temple in this remote setting. As outlined above, the region has no obvious natural resources to sustain such a program. But, unquestionably, the bottom line is that the Sasanian fire temple of Gach Dawar is a most impressive complex by any standard.

\section{POST FIRE TEMPLE ACTIVITY}

As briefly mentioned in the introduction, the complex of Gach Dawar was converted for industrial workshop use in the $10^{\text {th }}$ or $11^{\text {th }}$ century A.D (either late Abbasid period or Seljuq era). Material evidence for dating this workshop rests at present with the glazed ceramics with splash decoration and by two bronze objects - a lamp or make-up

\footnotetext{
${ }^{28}$ Antia 1900: 20-21.

${ }^{29}$ Huff 1972: 517-540.
} 
container, and a vessel bird finial recovered within the building. ${ }^{30}$ The accumulation of considerable deposits of ash within the Chahar Taq and surrounding corridors as well as the presence of a number of pits containing ash dug into the floor of rooms 9 and 16 are the testimony of a specialized workshop use (Fig. 11). It was suggested that the workshop may have involved glass working as a great number of glass fragments were found within the building. ${ }^{31}$ Excavations did not reveal a sherd of evidence to indicate the nature of activity that once carried out in the workshop. No evidence of kiln furniture, waste material, unshaped glass fragments, glass fragments distorted by heat, glass slag, etc, were recovered that one can confidently claim that it was a workshop for glass making. The presence of glass fragments alone does not provide a sufficient argument for determining the type of activity conducted in the workshop. The glass pieces may have simply been fragments of vessels used by the Zoroastrian believers and/or individuals who worked in the workshop in the $10^{\text {th }}-11^{\text {th }}$ century.

Along the northern side of the building, there exist a few hearths containing ash. Given the stratigraphic confusion one cannot be assured that these hearths are contemporary with the industrial workshop or belonging to the subsequent periods.

\section{Bibliography}

Antia, E. K. 1900. Kârnâmak-i Artakhshîr Pâpakân: The Original Pahlavi Text, with Transliteration in Avesta Characters, Translation into English and Gujerati, and Selections from the Shâhnâmeh, Bombay, Fort Printing Press.

Azarnoush, M. 1989. "Mil-e Naqârah Hânah, A Complex of Two Čahâr-Tâqs in Eastern Fars", in L. De Meyer and E. Haerinck (eds.), Archaeologia Iranica et Orientalis:

\footnotetext{
${ }^{30}$ Keall 1982: 59.

${ }^{31}$ Keall 1981: 34; Idem 1982: 59.
} 
Miscellanea in Honorem Louis Vanden Berghe, 2 vols, Gent, Peeters Presse, vol. II: 651-662.

Boucharlat, R. and Lecomte, O. 1987. Fouilles de Tureng Tepe;1. Les periodes sassanides et islamiques, Paris, Recherche sur les Civilisations.

Boyce, M. 1966. “The Fire-Temples of Kerman”, Acta Orientalia XXX: 51-72.

- 1968. "On the Sacred Fires of the Zoroastrians", Bulletin of the School of Oriental and African Studies 31: 52-68.

- 1975. "On the Zoroastrian Temple Cult of Fire", Journal of the American Oriental Society 95: 454-465.

- 1979. Zoroastrians, their Religious Beliefs and Practices, London, Routledge and Kegan Paul.

- 1987. “Ātaš", in E. Yarshater ed., Encyclopedia Iranica, vol. III, Fasc. 1, London and New York, Routledge and Kegan Paul, 1-5.

Callieri, P. 2014. Architecture et représentations dans l'Iran sassanide, Paris, Association pour l'Avencement des Études Iraniennes.

Choksy, J. K. 2006. "Altars, Precincts, and Temples: Medieval and Modern Zoroastrian Praxis", Iran VLIV: 327-346.

- 2007. "Reassessing the Material Contexts of Ritual Fires in Ancient Iran", Iranica Antiqua XLII: 229-269.

Drower, E. S. 1944. "The Role of Fire in Parsi Ritual", The Journal of the Royal Anthropological Institute of Great Britain and Ireland 4: 75-89.

Erdmann, K. 1941. Das iranische Feuerheiligtum, Leipzig.

Godard, A. 1938. "Les monuments du feu", in A. Godard (ed.), Athār-é Irān, 3 vols. Haarlem, vol. III: 7-80.

Gropp, G. 1969. "Die Funktion des Feuertempels der Zoroastrier", Archäologische Mitteilungen aus Iran 2: 147-175, Tafelen. 61-68.

Huff, D. 1972. "Der Takht-i Nishin in Firuzabad", Archäologischer Anzeiger 87: 517540.

- 2002. "Takkt-e Solaymān", in E. Yarshater (ed.), Encyclopedia Iranica http://www.iranicaonline.org/articles/takt-e-solayman 
- 2004. "Takht-I Suleiman. Sasanian Fire Sanctuary and Mongolian Palace", in Thomas Stöllner et al (eds.), Persiens Antike Pracht: Bergbau, Handwerk, Archäologie; Katalog der Ausstellung des Deutschen Bergbau-Museums Bochum vom 28. November 2004 bis 29. Mai 2005, 2 vols. Bochum, Deutsches Bergbau-Museum, 462-471.

- 2008. "The Functional Layout of the Fire Sanctuary at Takht-I Sulaimān”, in D. Kennet and P. Luft (eds.), Current Research in Sasanian Archaeology, Art and History, Oxford, BAR International Series 1810: 1-13.

- 2011."Problems of Votive Offerings in Zoroastrian Iran", Archäologische Mitteilungen aus Iran und Turan 43: 79-111.

Kaim, B. 2004. "Ancient Fire Temples in the Light of the Discovery at Mele Hairam", Iranica Antiqua XXXIX: 324-337.

Keall, E. J. 1979. “Qal'eh-i Yazdigird”, Iran XVII: 158-159.

- 1982. "Qal'eh-I Yazdigird: An Overview of the Monumental Architecture", Iran XX: $51-72$.

- 1983. "A Persian Castle on the Silk Road", in J. E. Vollmer et al. (eds.), Silk Roads. China Ships: An Exhibition of East-West Trade, Toronto, Royal Ontario Museum: $40-52$.

- 1994. "How many Kings did the Parthian King of Kings Rule?", Iranica Antiqua XXIX: 253-272.

- 2008. "Achaemenian, Parthian, and Sasanian Persian Civilizations", in D. M. Pearsall (ed.), Encyclopedia of Archaeology, 3 vols, Amsterdam, Elsevier/Academic Press 1: 819-827.

Keall E. J. and Keall M. J. 1981. "The Qal'eh-i Yazdigird Pottery: A Statistical Approach", Iran XIX: 33-80.

Kotwal, F. M. and Choksy J. K. 2004. "To Praise the Souls of the Deceased and the Immortal Spirits of the Righteous Ones: The Staomi or Stūm Ritual's History and Functions", in M. Stausberg (ed.), Zoroastrian Rituals in Context, Leiden, Brill.

Moradi, Y. 2016. "On the Sasanian Fire Temples: New Evidence from the Čahār-Tāq of Mil-e Milagah” Parthica 18: 31-52. 
Naumann, R. 1960. "Takht-i-Suleiman and Zindan-i-Suleiman: Various Excavations in 1959”, in A. Pope (ed.), A Survey of Persian Art from Prehistoric Times to the Present: Prehistoric Times to the end of the Sasanian Empire, 15 vols. London, XIV: 3050-3060.

Naumann, R., Huff, D., Kleiss, W., Boehmer, R.M., Wiegartz, H. 1965. "Takht-i Suleiman und Zendan-i Suleiman: Vorläufiger Bericht über die Ausgrabungen in den Jahren 1963 und 1964”, Archäologischer Anzeiger 90: 619-802.

Rahbar, M. 1394 (2015), “Aya Imamzadeh-ye Rosat-ye Mohammad Vali Beig yek Atashkadeh Ast? \{Is the Islamic Holy Shrine in Mohammad Vali Beig Vilage a Fire Temple?\}", in Sh. Zareh (ed.), An Archaeological Overview on Khorasan: A Collection of Papers for the 3rd Congress of Iranian Young Archaeologists, Tehran, Pazhuheshgah-e miras-e farhangi va gardeshgari, 92-98.

Schipmann, K. 1971. Die iranischen Feuerheiligtümer, Berlin, de Gruyter.

Tabarī. 1999. Ta'rīk al-rusul wa'l-mulūk, ed. Ehsan Yarshater, 40 vols., translated by various scholars as The History of al-Ṭabarī, V, trans. C. E. Bosworth as The Sāsānids, the Byznatines, the Lakmids, and Yemen, Albany, State University of New York Press: vol. 5.

Vanden Berghe, L. 1968. On the Track of the Civilizations of Ancient Iran: A Belgian Contribution to Knowledge of the Iranian Historical Heritage, Brussels, Ministry of Foreign Affairs and External Trade.

Yaghmaee, E. 1394 (2015). “Chahar Taq-ye Mohammad Abad-e Dashtestan-Borazjan [Chahar Taq of Mohammad Abad in Dashtestan-Borazjan]”, Bastanpazhuhi 17: 5058. 